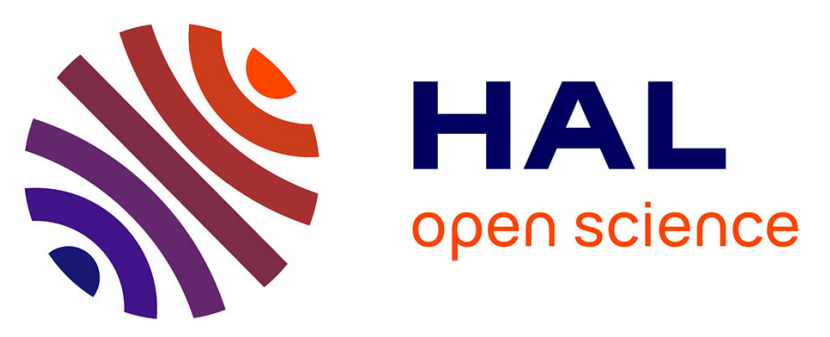

\title{
Monitoring of ambient fine particulate matter concentrations from space: application to European and African cities
}

Jean-François Léon, Cathy Liousse, Corinne Galy-Lacaux, Thierno Doumbia, Hélène Cachier

\section{To cite this version:}

Jean-François Léon, Cathy Liousse, Corinne Galy-Lacaux, Thierno Doumbia, Hélène Cachier. Monitoring of ambient fine particulate matter concentrations from space: application to European and African cities. Proceedings of SPIE, the International Society for Optical Engineering, 2010, Sensors, Systems, and Next-Generation Satellites XIV, 7826 (2A), 10.1117/12.864954 . hal-00996013

\section{HAL Id: hal-00996013 https://hal.science/hal-00996013}

Submitted on 9 Aug 2021

HAL is a multi-disciplinary open access archive for the deposit and dissemination of scientific research documents, whether they are published or not. The documents may come from teaching and research institutions in France or abroad, or from public or private research centers.
L'archive ouverte pluridisciplinaire HAL, est destinée au dépôt et à la diffusion de documents scientifiques de niveau recherche, publiés ou non, émanant des établissements d'enseignement et de recherche français ou étrangers, des laboratoires publics ou privés.

\section{다)(1) $(5$}

Distributed under a Creative Commons Attribution - NonCommerciall 4.0 International 


\title{
Monitoring of ambient fine particulate matter concentrations from space: Application to European and African cities
}

\author{
Jean-François Léon ${ }^{a}$, Cathy Liousse ${ }^{a}$, Corinne Galy-Lacaux ${ }^{a}$, Tierno Doumbia ${ }^{a}$, Hélène \\ Cachier $^{b}$ \\ ${ }^{a}$ Laboratoire dAérologie, Observatoire Midi-Pyrénées, CNRS-Université Paul Sabatier, \\ Toulouse, France; \\ ${ }^{b}$ Laboratoire des Sciences du Climat et de l'Environnement, CEA-CNRS, Gif-sur-Yvette, \\ France
}

\begin{abstract}
Air pollution is a major issue for global environment as well as human health and well-being. Recently, satellites which are equipped with relevant air quality instruments have been placed into orbit. In this paper, we first present a review on satellite remote sensing of particulate pollution. We then present new results for Europe and on African cities particulate air pollutants using POLDER satellite data. Based on satellite AOD observations, we show that the number of days exceeding the $15.4 \mu \mathrm{g} / \mathrm{m}^{3}$ threshold is twice frequent in Ouagadougou, BurkinaFaso than in Paris, France. At the regional scale, we observe that the northern coast of the golf of Guinea is dramatically impacted by poor air quality.
\end{abstract}

Keywords: Aerosol, Pollution, Satellite, Health, Africa

\section{INTRODUCTION}

Air pollution is a major issue for global environment as well as human health and well-being. Expose to airborne fine particulate matter is associated with adverse human health effects. ${ }^{1,2}$ According to Aman et al., ${ }^{3}$ the mean statistical loss in life expectancy estimated in 2000 that can be attributed to anthropogenic contributions to fine particulate matter (PM2.5) is 9 months for the EU-25 countries. In their recent study, Pope et al. ${ }^{4}$ evaluate the change in life expectancy in relation with differential change in fine particulate air pollution (PM2.5) that occurred in the United States during the 1980s and 1990s. They found that a decrease of $10 \mu \mathrm{g} / \mathrm{m}^{3}$ in the concentration of fine particulate matter was associated with an estimate increase in mean life expectancy of 0.61 $( \pm 0.20)$ year. In response to the risk due to pollution fine particles, governments have adopted regulations for the monitoring of PM ambient concentrations and mitigation (Clean Air Act US congress in 1990, Clean Air for Europe and the 1996 framework directive, ...). Several national environmental agencies monitor PM10 and PM2.5 concentrations through a dense but geographically limited network. Few long-term measurement sites exist in rapidly developing countries where concentrations and estimated health impacts are greatest. Satellite observation can bring an new insight in particulate air quality monitoring by providing near global observations of aerosol concentrations and then substantially improve estimates of population exposure to PM.

\section{POLLUTION PARTICULATE MATTER}

Particulate air pollutants (particulate matter; PM or aerosols) consist of material in solid or liquid phase suspended in the atmosphere. They may be either emitted into the atmosphere (primary pollutants) or formed within the atmosphere itself (secondary pollutants). Aerosols have impact on human health as they can easily penetrate into the respiratory system. There capacity to penetrate the respiratory track and their impact on the epithelium depends on their size and chemical composition which is diverse by nature. Aerosol composition can be made of a highly complex mixture of different chemical component. The ultra-fine mode is usually dominated by carbonaceous particles (black carbon and particulate organic matter) while the accumulation modes show an internal mix of inorganic salts and particulate organic matter with a core of either black carbon or mineral dust. Particulate matter (PM) is continuously monitored at air quality station. PM10 is the mass concentration of aerosol with an aerodynamic diameter less than $10 \mu \mathrm{m}$. In the same way, PM2.5 and PM1 corresponds to mass concentration of particles having an aerodynamic diameter less than 2.5 and $1 \mu \mathrm{m}$, respectively. PM10 contains coarse material and mineral dust can be a major contributor. ${ }^{5}$ 


\begin{tabular}{|c|c|c|c|c|}
\hline Author & Sensor & PM2.5/PM10 & Linear regression & $\mathrm{R}$ \\
\hline \multirow[t]{3}{*}{ Wang and Christopher ${ }^{6}$} & MODIS (Terra) & PM2.5 24hr & $77.0 \times A O D-0.23$ & 0.67 \\
\hline & MODIS (Aqua) & PM2.5 24hr & $68.6 \times A O D+1.93$ & 0.76 \\
\hline & Average & PM2.5 24hr & $72.3 \times A O D+0.85$ & 0.98 \\
\hline Chu, et al. ${ }^{7}$ & MODIS & PM10 & $54.7 \times A O D+8.0$ & 0.82 \\
\hline \multirow[t]{2}{*}{ Engel-Cox, et al ${ }^{8}$} & MODIS & PM2.5 & $22.6 \times A O D+6.4$ & 0.43 \\
\hline & & PM2.5 24hr & $18.7 \times A O D+7.5$ & 0.40 \\
\hline Liu, et al. ${ }^{9}$ & MISR & PM2.5 & $\mathrm{N} / \mathrm{A}$ & 0.8 \\
\hline Engel-Cox, et al. ${ }^{10}$ & MODIS & PM2.5 24hr & $64.8 \times A O D+1.76$ & 0.76 \\
\hline Liu, et al., ${ }^{11}$ & MISR & PM2.5 & & \\
\hline Al-Saadi, et al. ${ }^{12}$ & MODIS & PM2.5 & $62 \times A O D$ & \\
\hline Gupta, et al. ${ }^{13}$ & MODIS & PM10 & $141 \times A O D$ & 0.96 \\
\hline Koelemeijer, et al. ${ }^{14}$ & MODIS & PM10 & $214 \times A O D-42.3$ & 0.58 \\
\hline Kacenelenbogen, et al. ${ }^{15}$ & POLDER & PM2.5 & $26.6 \times A O D+13.2$ & 0.7 \\
\hline Gupta and Christopher ${ }^{16}$ & MODIS & PM2.5 & $29.4 \times A O D+8.8$ & 0.62 \\
\hline Hutchison $^{17}$ & MODIS & PM2.5 & $59.7 \times A O D-17.2$ & 0.98 \\
\hline Paciorek et al. ${ }^{18}$ & GOES-12 & PM2.5 24hr & $\mathrm{N} / \mathrm{A}$ & 0.5 \\
\hline \multirow[t]{2}{*}{ An, et al. ${ }^{19}$} & MODIS & PM10 & $21.7 \times A O D+6.1$ & 0.92 \\
\hline & & PM2.5 & $31.1 \times A O D+5.1$ & 0.92 \\
\hline Schaap, et al. ${ }^{20}$ & MODIS & PM2.5 & $120 \times A O D+5.1$ & 0.72 \\
\hline
\end{tabular}

Table 1. List of correlative studies linking PM to AOD (adapted from Hoff and Christopher ${ }^{21}$ ).

\section{SATELLITE REMOTE SENSING}

During the last decade, satellite remote sensing was extensively used for aerosol monitoring because of their importance for climate. Satellite data can be directly used to improve air quality assessment, management and prediction. IDEA (Infusing satellite date into environmental air quality applications ${ }^{12}$ ) or the University of Maryland Baltimore County Smog blog (http://alg.umbc.edu/usaq/) are web applications which gather data from satellite missions, ground-based measurements and numerical models to analyze extreme pollution events and to improve air quality management for public benefit. The use of satellite data products for forecasting PM2.5 in chemical models is at its very beginning. Global climate models now use assimilation of standard satellite products to improve aerosol optical depth (AOD) forecasts. ${ }^{22,23}$ However there is no regional or global satellite PM product that can be used to constrain air quality simulation. Indeed the relationship between $\mathrm{AOD}$ and PM as it measured by air quality monitoring station is not straightforward. The AOD is an ambient column-integrated optical characteristic while PM is a dry mass concentration measured at a few meters above the ground. The ability of AOD to be a proxi for PM will depend on several factors including the vertical distribution of aerosol in the atmosphere, their intrinsic optical and microphysical properties, and their ability to condensate water vapor.

Most of the recently published studies rely on a direct comparison between ground-level PM (PM2.5 or PM10) with satellite retrieved AOD using a linear regression. Correlation coefficients are significant but can vary widely from one site to another. The contribution of boundary layer PM to the total aerosol optical depth can widely vary depending on local meteorology, including turbulence and convective mixing, or large-scale transport. Table 3 provides a list of correlation studies. Most of the analysis are performed regionally and for a short period of time and no universal relationship can really be drawn at the global scale. Due to the large remaining uncertainties in the AOD-PM relationship, it is quite difficult to provide a global satellite operational product. However a global conversion of AOD to PM was achieved by Van Donkelaar et al. ${ }^{24}$ They have used a global chemistry transport model to essentially provide information on the vertical distribution of aerosols in the atmosphere at the global scale. Indeed, aerosol remote sensing from space in the lowest first few hundred meters remains a challenging issue. The dependency of the result to the model ability to provide an accurate vertical distribution is a drawback of this method.

Rather than using a conversion factor, Kacenelenbogen et al. ${ }^{15}$ have established an AOD threshold for 

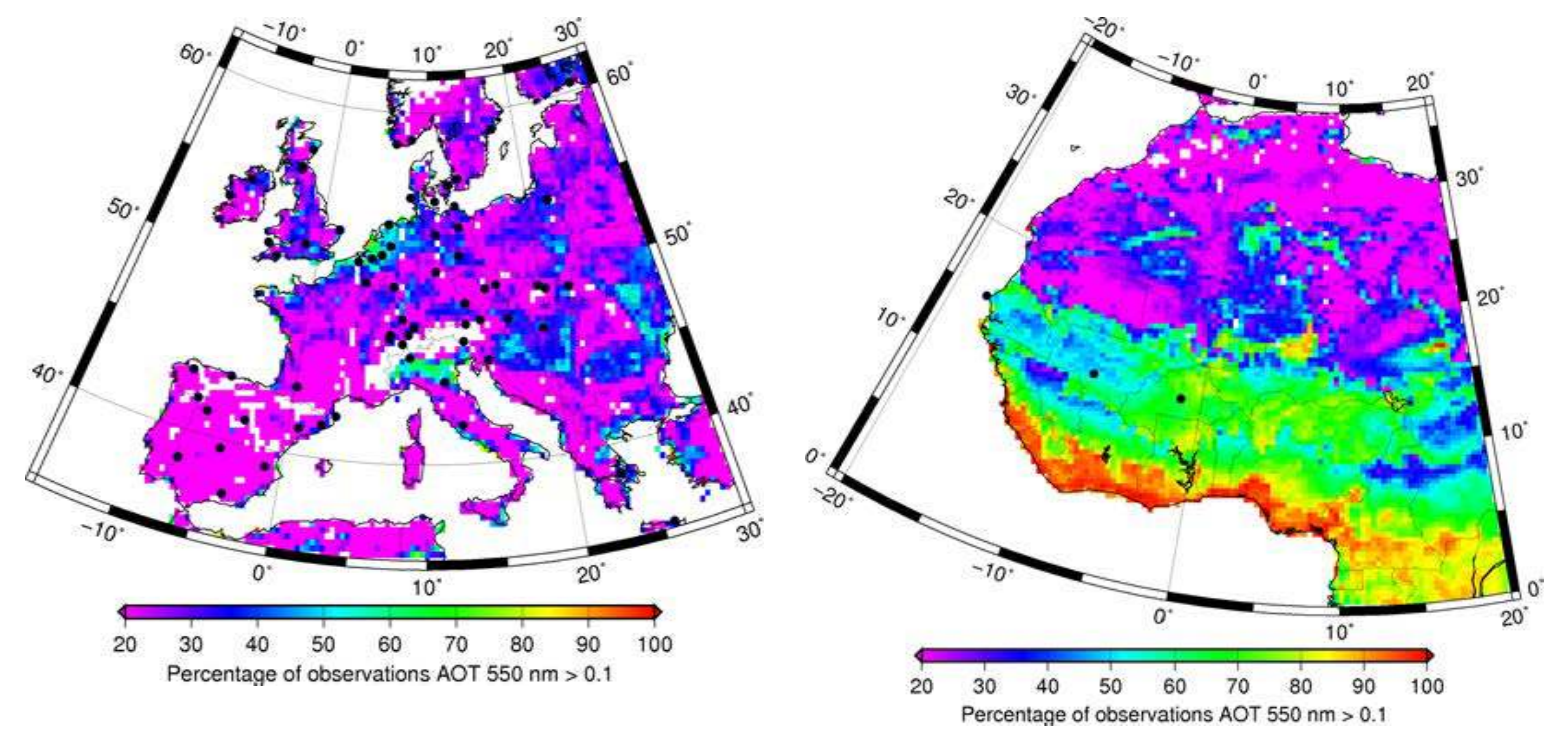

Figure 1. Percentage of POLDER/PARASOL observations during year 2008 with a fine mode AOD above 0.17.

which particulate air quality can be considered as good or moderate. This threshold has been assessed at 0.17 considering AOD at $440 \mathrm{~nm}$ given by POLDER instrument. Polarization of Earth's Reflectance and Directionality $\left(\right.$ POLDER $^{25}$ ) was one of the very first spaceborne instrument dedicated to aerosol monitoring at the global scale. POLDER is still operating aboard PARASOL satellite since 2005 and provide a daily picture of the global aerosol optical depth. POLDER AOD is derived using a technique based on the measurement of the top-of-the atmosphere polarization state of reflected light. It is highly sensitive to fine particles. ${ }^{26}$

\section{EUROPE}

We have followed the method proposed by Kacenelenbogen et al. ${ }^{15}$ and applied it to the PM2.5 data collected in the frame of the European Monitoring and Evaluation Programme (EMEP) over the period 2006-2008. 28 stations (see black dots on Figure 3) were selected for a total of 4634 daily observations. Using the AOD at 550 $\mathrm{nm}$, we have found an equivalent threshold for "moderate" AQ conditions at 0.1. Considering this threshold, more than $76 \%$ of daily average PM are correctly identified to be above $15.4 \mu \mathrm{g} / \mathrm{m}^{3}$. A linear regression through all the dataset gives a correlation coefficient $\mathrm{R}=0.5$, a slope of $60 \mu \mathrm{g} / \mathrm{m}^{3} /$ AOD unit and an intercept of 9 $\mu \mathrm{g} / \mathrm{m}^{3}$. Our results are very similar to those presented in Table 3 using the MODIS sensor. ${ }^{6,7,12}$ Figure 3 shows a map centered on Western Europe of the number of days exceeding this threshold over 2006-2008 using POLDER/PARASOL observations. Industrial and large urban areas such as the Po valley in Northern Italy or the Benelux are clearly identified as "hot spot" of poor particulate matter air quality.

\begin{tabular}{lll}
\hline Cities & $\begin{array}{l}\mathrm{PM} 10 \\
\mu \mathrm{g} / \mathrm{m}^{3}\end{array}$ & $\begin{array}{l}\mathrm{PM} 2.5 \\
\mu \mathrm{g} / \mathrm{m}^{3}\end{array}$ \\
\hline Lille, France $^{a}$ & 18 & 11 \\
Ouagadougou, Burkina-Faso $^{a}$ & 52 & \\
Bamako, Mali $^{b}$ & & 36 \\
Dakar, Senegal $^{c}$ & & 23 \\
\hline
\end{tabular}

Table 2. Average PM10 and PM2.5 concentrations for different cities ( ${ }^{a}$ From December 2007 to October $2008 ;{ }^{b}$ April 2008 to May $2009 ;{ }^{c}$ April 2008 to October 2008). 

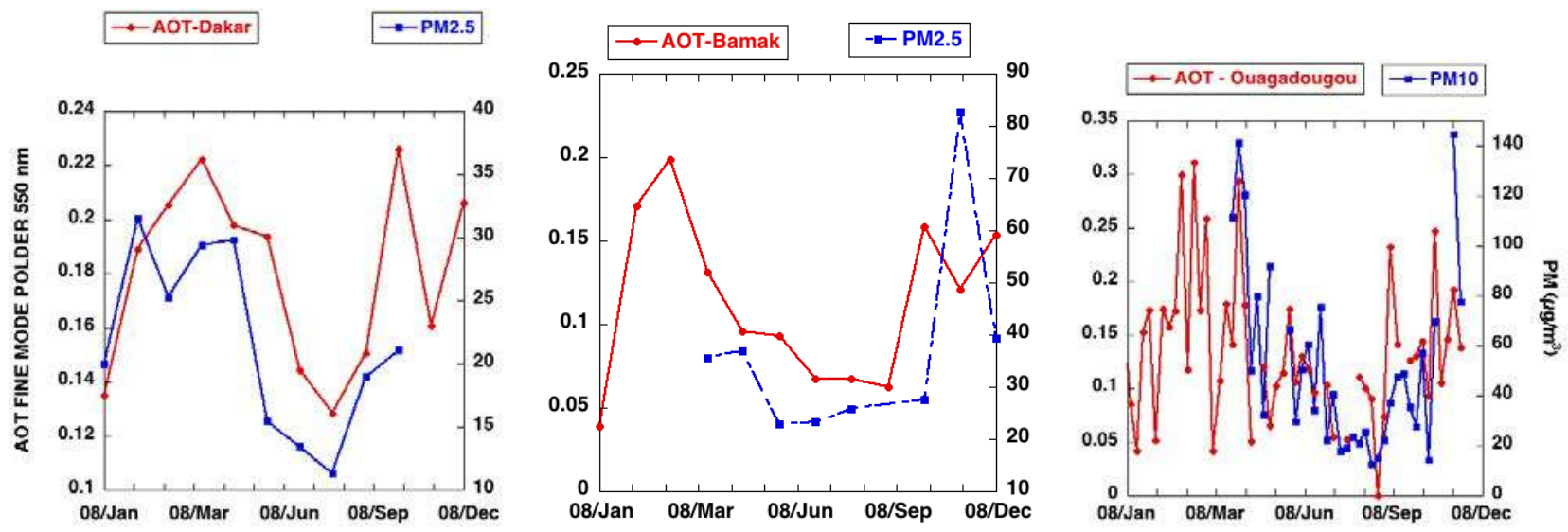

Figure 2. Comparison between monthly mean POLDER-derived fine mode AOT and PM2.5 in the city of (left) Dakar and (center) Bamako. Comparison between weakly mean POLDER-derived fine mode AOT and PM10 in the city of Ouagadougou.

\section{AFRICAN CITIES}

The urban population of Africa will double from 294 million in 2000 to 742 million in 2030 (source United Nations Population Funds). Adverse effect of poor air quality in African cities is crucial. There is a large diversity in aerosol chemical composition due to both natural (mineral dust, biomass burning due to agricultural waste burning or deforestation) and anthropogenic (poor quality fossil fuel or biofuel use) sources. The PM concentration are very high compared to north-western cities. Table 4 gives a comparison between average concentration recorded in Lille, France and 3 different cities in Northern Africa: Ouagadougou, Burkina-Faso, Bamako, Mali and Dakar, Senegal. As mineral dust in the Sahel region can contribute a lot to PM10, this can partially explains the large difference observed in the average concentrations between both cities of Lille and Ouagadougou. However, PM2.5 concentration are twice higher in Bamako than in Lille, indicating a large pollution due to anthropogenic activities.

We have compared the AOD derived from POLDER sensor aboard the PARASOL mission with the PM recorded in the 3 aforementioned African cities (Figure 5). The PM data were acquired on a weakly basis during ground-based field experiments. The variation in monthly mean AOD and PM2.5 shows the same tendency in Dakar, except in October. In Bamako, both PM and AOD have low tendency during the summer months but their variation differs significantly at the end of the year. During summer, mass concentrations and AOD are low due to the monsoon rain. However some extreme events in PM2.5 are not detected in the AOD. We also observe a similarity in the PM10 and AOD variation on a weakly basis over Ouagadougou.

Considering the threshold established by Kacenelenbogen et al. ${ }^{15}$ the number of days in "moderate" air quality category with respect to PM is $64 \%$ in Ouagadougou and 53\% in Bamako (percentage over 2006-2008 period). As a comparison, this percentage is $31 \%$ in Paris, France. Figure 5 shows the seasonal cycle of poor air quality in Bamako. The worst conditions are observed in May. The number days in the "moderate" AQC decreases during the rainy season (July-August). Applying this threshold to the whole western Africa (Figure 3 on the right) shows that most of the coasts surrounding the Golf of Guinea are $90 \%$ of the time with degraded air quality conditions.

\section{CONCLUSIONS AND PERSPECTIVES}

Particulate pollution monitoring from space remains a challenging issue. Many studies have been devoted to quantitative assessment of PM from satellite derived aerosol optical depth over Europe and the US. In this paper, we have first used the EMEP PM2.5 data to verify that the threshold established by Kacenelenbogen et al. ${ }^{15}$ on POLDER satellite AOD can be used to identify polluted days. Then we have compared the POLDER fine mode optical depth to PM recorded in the major African cities of Bamako, Ouagadougou and Dakar. The similarities 


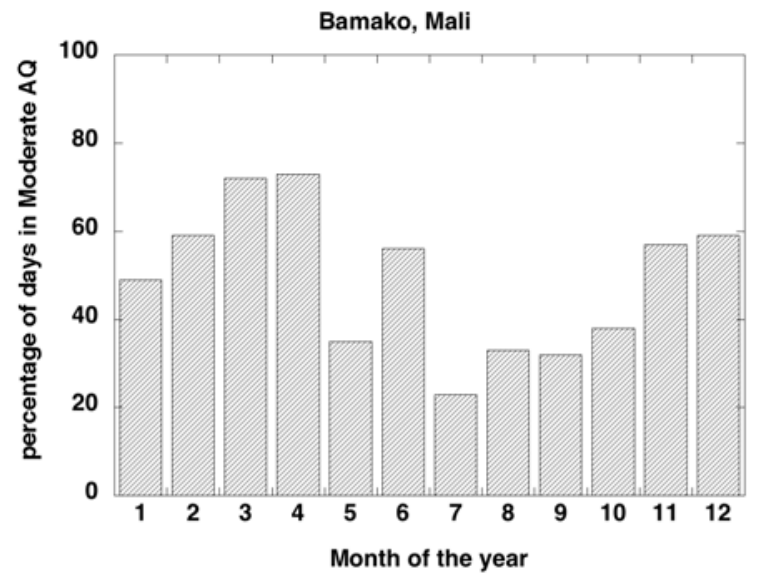

Figure 3. Monthly percentage of days with a POLDER/PARASOL AOD at $550 \mathrm{~nm}$ above 0.1 in Bamako, Mali from 2006 to 2008 .

in the monthly and weakly trend of both PM and AOD indicates that this parameter might also be used as an estimator of PM concentration over major African cities. Regional picture of degraded air quality clearly higlights the coastal area in the northern part of the golf of Guinea.

Particulate pollution satellite remote sensing for air quality management and health risk assessment is in its infancy. Satellite missions dedicated to climate survey provide both quantitative and qualitative valuable information for PM monitoring. Further analysis of the data collected by the CALIOP lidar aboard CALIPSO mission (NASA-CNES) should provide crucial information on the aerosol vertical structure, which is a critical parameter for particulate pollution monitoring from space. However a dedicated air quality monitoring mission is still required for a quantitative assessment of pollution from space.

\section{ACKNOWLEDGMENTS}

In situ data have acquired in the frame of CORUS-POLCA program. The authors thank Bernard Nana for providing PM data in Ouagadougou. The author also thank the ICARE thematic center for providing an easy access to satellite data and products used in this paper. We thank the Norvegian meteorological institute for giving an access to the EMEP data.

\section{REFERENCES}

1. Dockery, D., Pope III, C., Xu, X., Splenger, J., Ware, J., Fay, M., Ferris, B., and Speizer, F., "An association between air pollution and mortality in Six U.S. cities," The New England Journal of Medicine 329, 17531759 (1993).

2. Pope III, C., Dockery, D., and Schwartz, J., "Review of epidemiological evidence of health effects of particulate air pollution," Inhalation Toxicology 7, 1-18 (1995).

3. Aman, M., Cabala, R., Cofala, J., Heyes, C., Klimont, Z., Schöpp, W., Tarrason, L., Simpson, D., Wind, P., and Jonson, J.-E., 'CAFE scenario analysis Report Nr.2: The 'current legislation' and the 'Maximum technically feasible reduction' cases for the CAFE baseline emission projections. Background paper for the meeting of the CAFE working group on target setting and policy advice," tech. rep., International Institute for Applied Systems Analysis (2004).

4. Pope III, C., Ezzati, M., and Dockery, D., "Fine-particulate matter air pollution and life expectancy in the united states," New England Journal of Medicine 360(4), 376-386 (2009).

5. Putaud, J.-P., Raes, F., et al., "A European aerosol phenomology -2: chemical characteristics of particulate matter at kerbside, urban, rural and background sites in Europe," Atmos. Environ. 38, 2579-2595 (2004).

6. Wang, J. and Christopher, S., "Intercomparison between satellite-derived aerosol optical thickness and PM2.5 mass: Implications for air quality studies," Geophys. Res. Lett. 30(21), 2095 (2003). 
7. Chu, D., Kaufman, Y., Zibordi, G., Chern, J., Mao, J., Li, C., and Holben, B., "Global monitoring of air pollution over land from the Earth observing system-Terra Moderate imaging spectroradiometer (MODIS)," J. Geophys. Res. 108(D21), 4661, doi:10.1029/2002JD003179 (2003).

8. Engel-Cox, J., Holloman, C., Coutant, B., and Hoff, R., "Qualitative and quantitative evaluation of MODIS satellite sensor data for regional and urban scale air quality," Atmos. Environ. 38, 2495-2509 (2004).

9. Liu, Y., Franklin, M., Kahn, R., and Koutrakis, P., "Using aerosol optical thickness to predict groundlevel PM2.5 concentrations in the St. Louis area: A comparison between MISR and MODIS," Rem. Sens. Environ. 107, 33-44 (2007).

10. Engel-Cox, J., Hoff, R., Rodgers, R., Dimmick, F., and et al., "Integrating lidar and satellite optical depth with ambiant monitoring for 3-Dimensional particulate characterization," Atmos. Environ. 40, 8056-8067 (2006).

11. Liu, Y., Sarnat, J., Kilaru, A., Jacob, D., and Koutrakis, P., "Estimating ground-level PM2.5 in the Eastern United-States using satellite remote sensing," Environ. Sci. Technol. 39, 3269-3278 (2005).

12. Al-Saadi, J., Szykman, J., Pierce, R., Kittaka, C., Neil, D., Chu, D., Remer, L., Gumley, L., Prins, E., Weinstock, L., MacDonald, C., Wayland, R., Dimmick, F., and Fishman, J., "Improving national air quality forecasts with satellite aerosol observations," Bull. of Amer. Meteor. Soc. 86(9), 1249-1261 (2005).

13. Gupta, P., Christopher, S., Wang, J., Gehrig, R., Lee, Y., and Kumar, N., "Satellite remote sensing of particulate matter and air quality assessment over global cities," Atmos. Environ. 40, 5880-5892 (2006).

14. Koelemeijer, R., Homan, C., and Matthijsen, J., "Comparison of spatial and temporal variation of aerosol optical thickness and particulate matter over Europe," Atmos. Environ. 40, 5304-5315 (2006).

15. Kacenelenbogen, M., Léon, J.-F., Chiapello, I., and Tanré, D., "Characterization of aerosol pollution events in France using ground-based and POLDER-2 satellite data," Atmos. Chem. Phys. 6, 4843-48-49 (2006).

16. Gupta, P. and Christopher, S., "Particulate matter air quality assessment using integrated surface, satellite, and meteorological products: Multiple regression approach," J. Geophys. Res 114(D14205) (2009).

17. Hutchison, K., "Applications of MODIS satellite data and products for monitoring air quality in the state of Texas," Atmos. Environ. 37, 2403-2412 (2003).

18. Paciorek, C., Liu, Y., Moreno-Macias, H., and Kondragunta, S., "Spatio-temporal associations between GOES aerosol optical depth retrievals and ground-level PM2.5," Environ. Sci. Technol. 42, 5800-5806 (2008).

19. An, X., Zhu, T., Wang, Z., Li, C., and Wang, Y., "Analysis of heavy air pollution episode occured in Beijing," Atmos. Chem. Phys. 9, 909-925 (2008).

20. Schaap, M., Apituley, A., Timmermans, R., Koelemeijer, R., and de Leeuw, G., "Exploring the relation between aerosol optical depth and PM2.5 at Cabauw, the Netherlands," Atmos. Chem. Phys. 9, 909-925 (2008).

21. Hoff, R. and Christopher, S., "Remote sensing of Particulate Pollution from Space: Have we reached the promised land ?," J. Air Waste Manage. Assoc. 59, 645-675 (2009).

22. Beneditti, A., Morcrette, J.-J., Boucher, O., Dethof, A., Engelen, R., Fisher, M., Flentje, H., Huneeus, N., Jones, L., Kaiser, J., Kinne, S., Mangold, A., Razinger, M., Simmons, A., and Suttie, M., "Aerosol analysis and forecast in the ECMWF integrated forecast system. Part II: Data assimilation.," J. Geophys. Res. 114(D13205) (2009).

23. Zhang, J., Reid, J., Westphal, D., Baker, N., and Hyer, E., "A system for operational aerosol optical depth data assimilation over global oceans," J. Geophys. Res. 113(D10208), doi:10.1029/2007JD009065 (2008).

24. Van Donkelaar, A., Martin, R., and Park, R., "Estimating ground-level PM2.5 using aerosol optical depth determined from satellite remote sensing," J. Geophys. Res. 111(D21201), 1-10, doi:10.1029/2005JD006996 (2006).

25. Deschamps, P. Y., Bréon, F. M., Herman, M., Buriez, J. C., Deuzé, J. L., Bricaud, A., Leroy, M., Podaire, A., and Sèze, G., "The POLDER mission: Instrument characteristics and scientific objectives," IEEE Trans. Geosci. Remote Sens. 32, 598-615 (1994).

26. Deuzé, J.-L., Bréon, F.-M., Devaux, C., Goloub, P., Herman, M., Lafrance, B., Maignan, F., Marchand, A., Nadal, F., Perry, G., and Tanré, D., "Remote sensing of aerosols over land surfaces from POLDER-ADEOS-1 polarized measurements," J. Geophys. Res. 106, 4913-4926 (2001). 